\title{
Anatomical Characters of Shoot Apical Meristem (SAM) on Bulbil Porang (Amorphophallus muelleri Blume) At the End of Dormancy Period
}

\author{
Muhammad Naufal $\mathrm{Afifi}^{1}$, Nunung Harijati ${ }^{2}$, Retno Mastuti ${ }^{2}$ \\ ${ }^{1}$ Master Program of Biology, Faculty of Mathematics and Natural Sciences, University of Brawijaya, Malang, Indonesia \\ 2Department of Biology, Faculty of Mathematics and Natural Sciences, University of Brawijaya, Malang, Indonesia
}

\begin{abstract}
Porang is one species member of the genus Amorphophallus. In Indonesia, Porang is cultivated extensively because it has a high economic value. There is three seeded material available for planting. One of seeded material is bulbil. Bulbil is a vegetative reproductive organ of Porang which is located in the branch of the leaf. Bulbil has 3 - 4 months dormancy period. The dormancy period will end marked with shoot growth. Morphologically, many tubercles were found on the bulbil peel. The tubercle scattered throughout the bulbil peel and become bud growth locus. Shoots on bulbil will grow from the tubercle and only in the adaxial part, contrary do not grow from the abaxial part. This study aim to compare the anatomy of shoot apical meristem (SAM) in the adaxial and abaxial parts of bulbil at the end of the dormancy period, i.e 100 days after harvest (DAH), $110 \mathrm{DAH}, 120 \mathrm{DAH}$, and $130 \mathrm{DAH}$. Anatomical structures of bulbil were observed by semi-permanent preparations. The results showed that the anatomical structures of the adaxial and abaxial parts of bulbil Porang had differences in SAM development, leaf primordia, primary thickening meristem (PTM) and procambium.
\end{abstract}

Keywords: Anatomy, Bulbil Porang, Dormancy, Shoot Apical Meristem.

\section{INTRODUCTION}

Porang (Amorphophallus muelleri Blume) is a member of Araceae [1] which in Javanese society is known asiles-iles [2]. At least three growth periods are needed to be harvested. Since the first planting period it can produce aerial tubers called bulbil. It grows on leaf branches which can reach 20 bulbils per plant [3]. Porang can be found in tropical and subtropical regions. These scattered from Africa to Asia such as Japan and China. Previously it was found in India (Andaman), then scattered eastward in Myanmar, Thailand, and Indonesia [4].

In Indonesia, porang were distributed from western regions such as Sumatra to West Nusa Tenggara (NTB) and East Nusa Tenggara (NTT). Furthermore $A$. muelleri can be propagated both generative by seeds and vegetative by tubers and bulbils [5]. Extensively propagation of $A$. muelleri were applied by bulbil [6] because it has ability to grow independently into new plants [7]. Information regarding seeds and tubers has been widely reported [8], whereas studies related to bulbil need to be expanded to supply porang

* Correspondence address:

Muhammad Naufal Afifi

Email : naufalbio@gmail.com

Address : Dept. Biology, University of Brawijaya, Veteran Malang, Malang 65145. references. Morphologically, bulbil has characteristics such as tubers but smaller in size. On the surface of bulbils peel, there are rough brown tubercles and these are bud growth locus [9]. Bulbil has a lot of tubercles scattered both adaxial and abaxial sides, but the shoots only arise from adaxial part. Morphologically, it were observable from the tubercle. However, anatomical structures of bulbils need to be investigated to obtain information of porang.

The terms adaxial and abaxial refers to Ezeabara [10]. At the end of the dormancy period, the tubercle in the adaxial part will transform into buds. Based on these empirical facts, this study aim to investigate the anatomy of bulbil both adaxial and abaxial parts after 3 months / 92 days after harvest (DAH) until the end of the dormancy period.

\section{MATERIALS AND METHODS}

Bulbils

The bulbil used has approximately $92 \mathrm{DAH}$ ( 3 months). The age was determined (calculated) since it was harvested from Porang. The bulbil was obtained from the district of Madiun, East Java. The bulbil weight ranged from 1.4-3.75 g with diameter of $14.5-19.5 \mathrm{~mm}$. Then the bulbils were germinated on the germination tray and placed in the laboratory at room temperature. When the bulbils 
were reacheds $100 \mathrm{DAH}$, it begins to be soaked in the FAA solution then followed periodically at 120 and $130 \mathrm{DAH}$ in the same way.

\section{Observation of Bulbil Anatomy}

The whole bulbil were cut into two equal parts (adaxial and abaxial). Both parts were sliced vertically with a razor blade than each slice was sliced with a microtome (Figure 1). Each slice was taken at a bud growth locus / tubercle in the bulbil peel. Sliced in the tubercle region intend to obtain the anatomical character of shoot apical meristem (SAM) in bulbil. The anatomy of bulbil was observed using semi-permanent slide which was preparations based on the modified Ruzin method [11]. The stages for making slides start from fixed the bulbil with FAA solution (Formaldehyde Acetic Acid Alcohol), bulbil which has been cut as described above clamped with carrot media and made using a microtome (clamp on hand microtome), sliced bulbil was soaked in $5 \% \mathrm{NaOH}$ during 5 minutes, followed by washing by distilled water for 5 minutes, then staining with Safranin 1\% for 3 minutes, then washing again with distilled water for 5 minutes. Furthermore, the slice-tissue were placed on a sliding glass, mounting with glycerin and covered by cover glass. To prevent evaporation of glycerin, sealed cover glass with transparent nail polish. Now the slides ready to observe with the light microscope and documented with a digital camera.

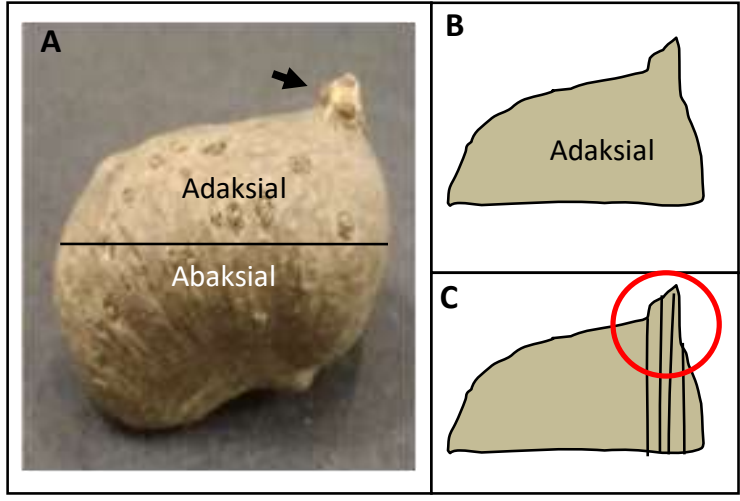

Figure 1. Cutting the bulbil Porang. (A: whole bulbil and its part, B: a part that will be sliced, C: slice in the tubercle area).

\section{Data Analysis}

The data obtained in this study are qualitative and quantitative. Qualitative data are the anatomical characters of the adaxial and abaxial parts that have been documented. Quantitative data was the result of the measurement of height and width of SAM. Both of these data were analyzed descriptively referring to various references.

\section{RESULT AND DISCUSSION}

Anatomical Character of Bulbil in Adaxial and Abaxial Parts

There are differences in SAM development in the adaxial and abaxial parts. The anatomical structure of bulbil at $100 \mathrm{DAH}$ has been observed the presence of SAM in the adaxial part (Fig. 2A). SAM organized as a dome and surrounded by two small leaf primordia. At the tip of SAM, tunica cells can be observed (Fig. 2A). It was composed of a 2-3 layer of cells. Tunica cells can divide quickly to intensify the surface and also differentiate to advance the development of SAM. At the bottom of SAM, procambium and primary thickening meristem (PTM) were observed. PTM is composed of semicircular cells. PTM cells and procambium surrounded byergastics substance organized as a black spot. The abaxial part of bulbil at $100 \mathrm{DAH}$ has not observed the development of SAM. Candidate SAM emerge in the epidermis and has a conical shape (Fig. 2E). Candidate of SAM was not growing well and incomparable with adaxial parts (Fig. 2A). It was indistinguishable between the dome of SAM and leaf primordia. Cell space was observed among groups of cells of various sizes and several points of ergastic substances.

Bulbil's anatomy in adaxial and abaxial parts at $110 \mathrm{DAH}$ has indicated the differences in SAM development, leaf primordia, and procambium. The anatomical structure of the adaxial part was observable the development of SAM and leaf primordial surrounding the SAM (Fig. 2B). Adaxial anatomy of bulbil aged $100 \mathrm{DAH}$ (Fig. 2A) has a SAM height of $621.05 \pm 142.05 \mu \mathrm{m}$ and a width of $670.47 \pm 194.16 \mu \mathrm{m}$. While the anatomy of SAM aged $110 \mathrm{DAH}$ increased in height and width, i.e. $629.91 \pm 30.14 \mu \mathrm{m}$ and $633.76 \pm 168.50 \mu \mathrm{m}$. Based on these measurements, there has been an increase in the height and width of SAM. However, in the abaxial part, SAM developments were unobserved (Fig. 2F). But both have similarities to the PTM structure. Around PTM there are meristematic cells with a small size (Fig. 2F). These meristematic cells may develop into SAM. But the development of SAM did not occur as in the adaxial part (Fig. 2B), only SAM candidates are observed around the 
epidermis. The SAM candidate has conical shaped and was bigger than the candidate of SAM at bulbil 100 DAH (Fig.2E).

Bulbil's anatomy at $120 \mathrm{DAH}$ has shown the development of SAM structure. In the adaxial part, the average height was $638.54 \pm 126.64 \mu \mathrm{m}$ and $774.43 \pm 230.67 \mu \mathrm{m}$ in width. In addition, leaf primordia were observed dome-circling (Fig. 2C). SAM structure and leaf primordia can be used as an indicator to determine the development of shoots. Furthermore, the presence of procambium under SAM was observed and the composition of the PTM was composed of semicircular cells. In contrast to the abaxial part, the development of SAM was unobserved (Fig. 2G). It was observed a candidate for a SAM like conical shaped in the epidermis. In addition, the presence of intercellular space and ergastic substances around the cell were observed.

Bulbil's anatomy at $130 \mathrm{DAH}$ has shown the significant development of SAM. It has an average height of $655.06 \pm 446.66 \mu \mathrm{m}$ and width of431.91 $272.61 \mu \mathrm{m}$. The average width value has decreased but the high value of SAM increase continuously (Table 1). The SAM structure looks so prominent, leaf primordia look wider and bigger (Fig. 2D). Procambium was observed under SAM and has sinuous shaped. Primary thickening meristem (PTM) was observed as previously and morphologically, shoot sprouts have emerged. The shoots emerge on the peel of the bulbil in white color. The shoots emerge from one of the tubercles on adaxial part of bulbil. Anatomically, SAM development has an impact morphologically on the growth of shoots.

An abaxial part at $130 \mathrm{DAH}$ has also shown the existence of SAM. However, SAM was unobserved in the dome shape as in the adaxial part (Fig. $2 \mathrm{H}$ ). It structures are undeveloped and leaf primordia were observed like a circle around the SAM. The structure of the leaf primordia was different from the adaxial part. Leaf primordia form a semicircle and emerge from two sides of SAM.

Comprehensively anatomical structures on adaxial at various ages $(100,110,120$, and 130 $\mathrm{DAH})$ was observablethe SAM structure, the presence of procambium, PTM, leaf primordia, tunica-corpus structure, and the emergence of several ergastic substances. Whereas in the abaxial part, the existence of SAM was unobserved. Only a few SAM candidates were observed around the tubercle-shaped epidermal cells. It was observed at $130 \mathrm{DAH}$ but did not indicate a dome. The anatomical structure of the abaxial part was also observed in the presence of intercellular spaces that are spread throughout the cell and the presence of ergastic substances. According to Steeves [12], SAM is formed since the embryogenesis stage and then develops into various important organs such as shoots, leaves, and stems. It can be observed with a microscope, composed of meristematic cells with different parts and functions. The PTM [13] is formed by several regular cell layers such as a circle of radius circles and is found in the peripheral zone. In some tubers and rhizomes, PTM is a collection of cells which can develop into the parenchyma, collateral vessels, and amphivasal vessels that produce adventitious roots.

Procambium is derived from vascular bundles association [13] then Krauss [14] states that the procambium is a tissue of primary meristems that will develop into the main vessels of the xylem and primary phloem vessels. Based on the observations of the anatomical structure of bulbil Porang at all ages, shows that meristematic cells are differentiated well and show a more mature phase in the adaxial part (Fig. A-D) compared to the abaxial part (Fig. E-H). The association of meristematic cells in the adaxial part was rows arranged to form a layered pattern with much smaller cell size. This shows that cells around SAM develop faster in the adaxial part. The existence of cells with a smaller size makes meristem cells have smaller vacuoles. The size can be an indicator when its staining. Meristematic cells can absorb color well because vacuoles were relatively small. While dyes will be difficult to penetrate cells other than meristematic because they have a larger vacuole. It has an effect on the color of the colored cells which paler tendency. Another factor that also important in the development of SAM according to Ganjari [9] was caused by internal factors in an accumulation of auxin hormones. Accumulation of auxin hormones in adaxial part was less than the abaxial portion. 

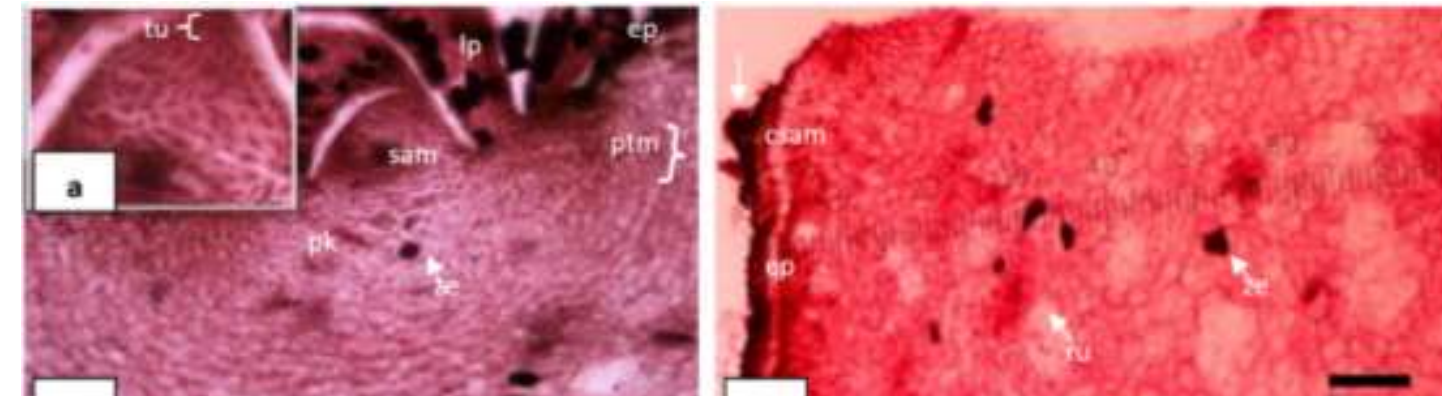

A

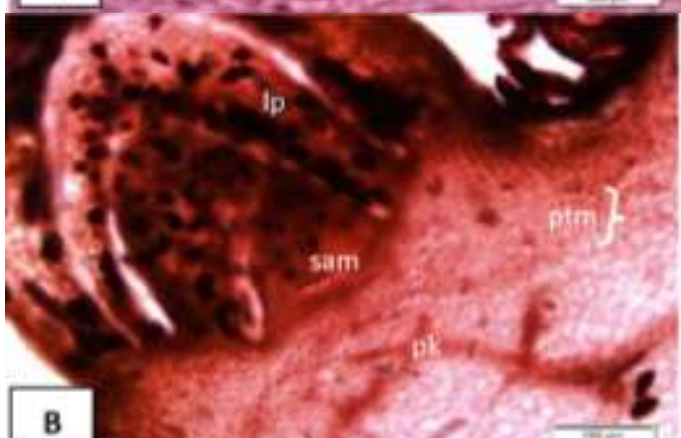

$\mathrm{E}$

$50 \mu \mathrm{m}$

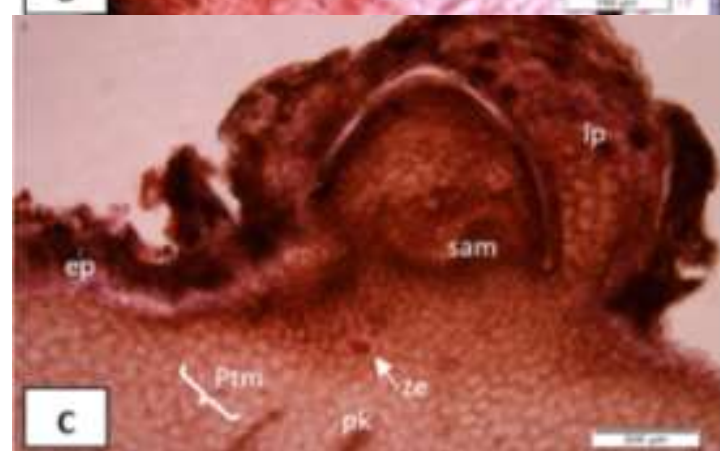

$\mathrm{F}$
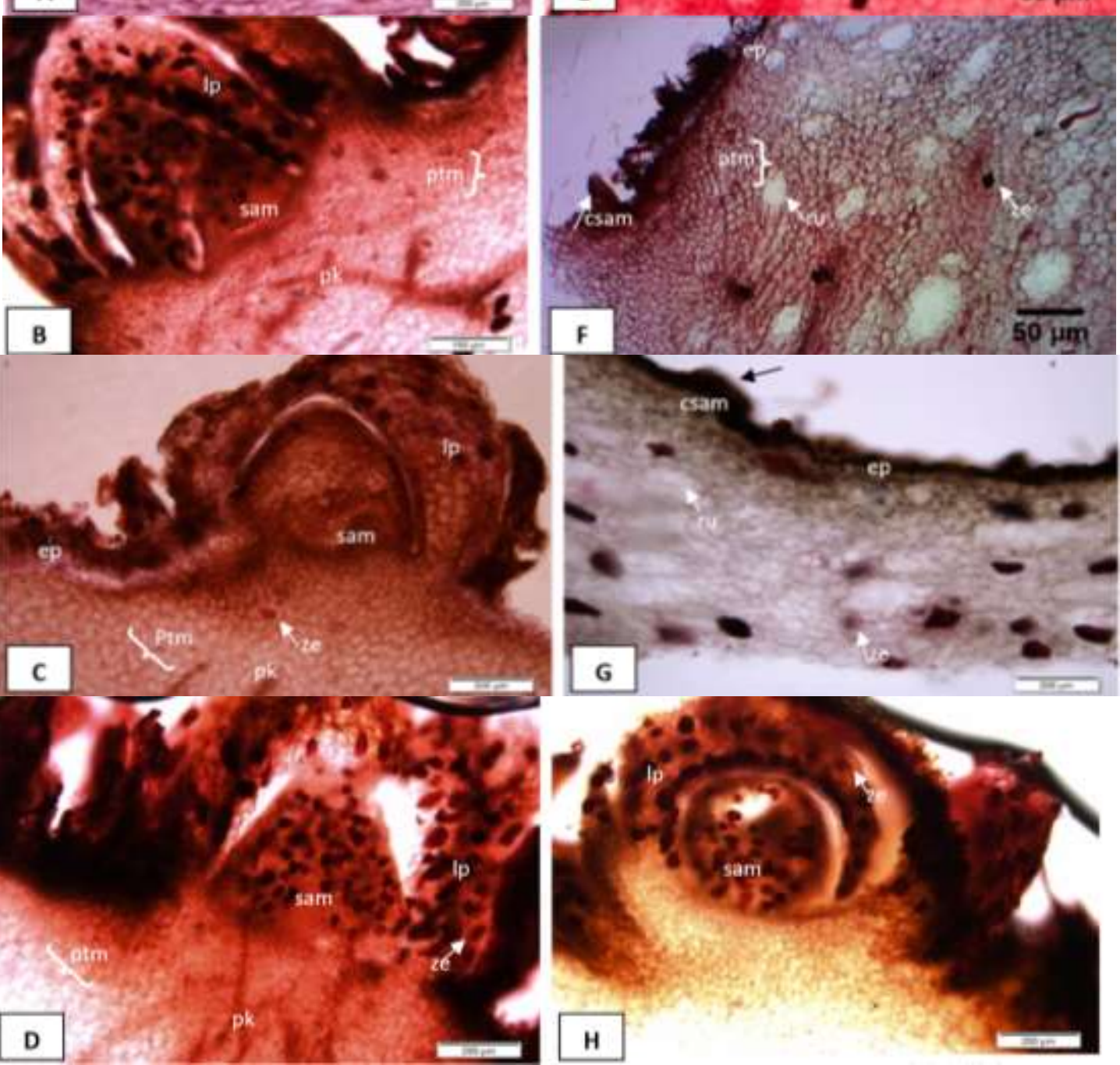

Figure 2.Anatomical structures of bulbil at various ages. A and E: $100 \mathrm{DAH}, \mathrm{B}$ and F: $110 \mathrm{DAH}, \mathrm{C}$ and G: $120 \mathrm{DAH}, \mathrm{D}$ and H: $130 \mathrm{DAH}$. (A-D anatomical structure of the adaxial part), (E-F anatomical structure of the abaxial part). sam; shoot apical meristem, ptm; primary thickening meristem, pk; procambium, tu; tunica, If; leaf primordia, ze; ergastic substance, ru; cell space, ep; epidermis, csam; candidate of sam.

Based on Sorce's [15], the potato tubers during dormancy have very much accumulated auxin hormones in the apical meristem and leaf primordia which are characterized by dark color when observed with a microscope. However, the tuber has sprouted then auxin appears to spread basipetally from the meristematic tissue to the proximal direction at the base of the shoot. It is 
also stated that there were a difference in auxin hormone level in the apical part of an organ with other organs that auxin movements occur basipetally from the apical to the basal, resulting in more accumulation of auxin in the apical portion compared to auxin in the basal [16]. The process of emergence of a shoot in the adaxial part of the bulbil was supported by apical dominance theories [9] that if the apical shoots have grown, the other shoot candidates will be eliminated. Anatomically, based on observations on bulbil of all ages can be observed epidermal cell structure. The epidermis of monocot plants has a multilayer epidermal structure as the outermost tissue [17] and has a solid cell with a neat structure as a characteristic often found in the Araceae family [18].

\section{Length and Width of SAM}

Based on the observation table the high value of SAM continues to increase from 100-130 DAH (Table 1). The increase in value indicates that there was a long increase in SAM cells.

Table 1. Table of length and wide bulbils.

\begin{tabular}{cll}
\hline $\begin{array}{c}\text { Bulbil age, } \\
\text { (the day after } \\
\text { harvest) }\end{array}$ & Width $(\boldsymbol{\mu m}) \pm$ SD & Height $(\boldsymbol{\mu m}) \pm$ SD \\
\hline $\mathbf{1 0 0}$ & $670.47 \pm 194.16$ & $621.05 \pm 142.05$ \\
$\mathbf{1 1 0}$ & $633.76 \pm 168.50$ & $629.91 \pm 30.14$ \\
$\mathbf{1 2 0}$ & $774.43 \pm 230.67$ & $638.54 \pm 126.64$ \\
$\mathbf{1 3 0}$ & $431.91 \pm 272.61$ & $655.06 \pm 446.66$ \\
\hline
\end{tabular}

However, there was a variation in the value of the SAM width, which was the highest value obtained in SAM aged 120 and the lowest in SAM aged $130 \mathrm{DAH}$. Theoretically, there will be an increase in cell weight in the growth process, but there may be constraints in the technique of sample slicing and the layout of bulbil ridges that are not the same at the time of slicing.

\section{CONCLUSION}

There are differences in the anatomical character of bulbil Porang in various ages. There are differences development of shoot apical meristems leaf primordia, primary thickening meristem, tunica, and procambium cells. The existence of various anatomical characters causes the growth of shoots in the adaxial part develops better than the abaxial part.

\section{REFERENCES}

[1] Mastuti, R., N. Harijati, E.L. Arumingtyas, W. Widoretno. 2018. Effect of bulbils position on leaf branches to plant growth responses and corms quality of Amorphophallus muelleri Blume. J.Exp.Life Sci. 8(1). 1-6.

[2] Harijati, N., R. Mastuti. 2014. Estimation of diverse porang (Amorphophallus muelleri Blume) age in the forest is based on the branching pattern of leaf petiolule. Res. J. Life Sci. 1(1). 20-26.

[3] Sumarwoto., Maryana. 2011. Pertumbuhan bulbil lles-lles (Amorphophallus muelleri Blume) berbagai ukuran pada beberapa jenis media tanaman. Jurnal ilmu kehutanan. 5(2). 91-98.

[4] Afifah, E., M.O. Nugrahani, Setiono. 2014. Peluang budidaya iles-iles (Amorphophallus spp.) sebagai tanaman sela di perkebunan karet. Warta Perkaretan. 33(1). 35-46.

[5] Gusmalawati, D., S. Indriyani, R. Azrianingsih. 2013. Anatomi dan histokimia organ generatif amorphophallus muelleri. Floribunda. 4(7). 175-180.

[6] Sulistiyo, H.R., L. Soetopo, Damanhuri. 2015. Eksplorasi dan identifikasi karakter morfologi porang (Amorphophallus muelleri B.) di jawa timur. Jurnal Produksi Tanaman. 3(5). 353361.

[7] Yang, P., L. Xu, H. Xu, Y. Tang, G. He, Y. Cao, Y. Feng, S. Yuan, J. Ming. 2017. Histological and transcriptomic analysis during bulbil formation in Lilium lancifolium. Plant Sci. 8. 1508.

[8] Indriyani, S., W. Widoretno. 2016. The effects of photoperiod to break dormancy of porang's (Amorphophallus muelleri Blume) tuber and growth. J. Life Sci. 3(3). 166-167.

[9] Ganjari, L. E. 2014. Pembibitan tanaman porang (Amorphophallus muelleri Blume) dengan model agroekosistem botol plastik. Widya Warta Journal. 43-58.

[10] Ezeabara, A.C., C.U. Okeke, A.I. Izundu, C.D. Udechukwu, G.O. Ogbuozobe. 2015. Comparative leaf and root anatomical studies of five varieties of Colocasia esculenta (L.) Schott. Int. J. Sci. Nat. 6(4). 576-580.

[11] Ruzin, S.E. 1999. Microtechnique and Microscopy Plant. Oxford University Press. New York.

[12] Steeves, T.A., I.M. Sussex. 1989. Patterns in Plant Development. Cambridge University Press. New York. 
[13] Rodrigues, C.A., M.E.M. Estelita. 2009. Morphoanatomy of the stem in Cyperaceae. Acta Bot. 23(3). 889-901.

[14] Krauss, B.H. 1948. Anatomy of the vegetative organs of the pineapple, Ananas comosus (L.) Merr. I. Introduction, organography, the stem, and the lateral branch or axillary buds. Bot. Gazette. 110. 159-217.

[15] Sorce, C., L. Lombardi, L. Giorgetti, B. Parisi. 2009. Indoleacetic acid concentration and metabolism changes during development in tubers of two potatoes (Solanum tuberosum) cultivars. J. Plant Physiol. 166. 1023-1033.

[16] Taiz, L., Zeiger. 2012. Plant physiology. Sinauer Associates, Inc. Publishers. Sunderland, Massachusetts.

[17] Kauff, F., P.J. Rudall, J.G. Gonran. 2000. Systematic root anatomy of asparagales and other monocotyledons, plant systematic an evaluation. Plant Syst. Evol.223. 139-154.

[18] Higaki, T., H.P. Rasmussen, W. J. Carpenter. 1984. A study of some morphological and anatomical aspects of Anthurium andreanum Lind. Hawaii Institute of Tropical Agriculture and Human Resources. The University of Hawaii,Manoa. 